\title{
Paving the Way Towards the ECTS System: Self- Assessment, Metacognition, and Professional Competence in a Literature Course for FL Teachers
}

\author{
Cristina PÉrez-VAlverde \\ University of Granada, Spain \\ Raúl RuIZ-CECILIA \\ University of Granada, Spain
}

Received: 4 December 2010 / Accepted: 27 March 2011

ISSN: $1697-7467$

\begin{abstract}
This paper presents a series of actions carried out in order to adapt one of the courses in the training curriculum of Foreign Language Teachers in the University of Granada (Spain) to the European Credit Transfer System (ECTS). The course focuses on literature teaching. The final aim of the aforementioned actions was that of promoting autonomous learning and reflective skills amongst trainees, in order to help them become responsible for their own professional development. The approach followed relies on the adoption of a competence-based curriculum and the introduction of self-assessment and metacognitive techniques. The evaluation of the experience reveals a significant improvement in the capacity of trainees to manage their own learning, in their linguistic competence, and in their handling of didactic resources and material. This research is part of a project financed by the Spanish Ministry of Science and Innovation (SEJ 2007-62329).
\end{abstract}

Keywords: Autonomous learning, self-assessment, competence-based model, literature teaching, metacognition

Hacia el sistema ECTS: autoevaluación, metacognición y competencia profesional en un curso de literatura para docentes de lenguas extranjeras

RESUMEN: Este artículo presenta las acciones llevadas a cabo en la adaptación de la asignatura Didáctica de la Literatura (Inglés), perteneciente al currículum de Maestro Especialidad Lengua Extranjera (Inglés) de la Universidad de Granada, al sistema del crédito europeo (ECTS). El objetivo final de dichas acciones era promover el aprendizaje autónomo y la capacidad reflexiva del alumnado, de forma que se responsabilizaran de su propio desarrollo profesional. El enfoque seguido se basa en la adopción de un currículum basado en competencias y en la introducción de técnicas de autoevaluación y metacognición. La evaluación de la experiencia pone de relieve una mejora significativa en la capacidad del alumnado para monitorizar su propio aprendizaje, en su competencia lingüística y en su manejo de materiales y recursos didácticos. Esta investigación forma parte de un proyecto financiado por el Ministerio de Ciencia e Innovación (SEJ 2007-62329).

Palabras clave: Aprendizaje autónomo, autoevaluación, modelo basado en competencias, didáctica de la literatura, metacognición. 


\section{InTRODUCTION}

The Spanish teacher training system is currently undergoing a process of change, ensuing from the need to move towards the creation of a European space for higher education, in accordance with the Bologna Declaration. The transition towards the ECTS (European Credit Transfer System) involves a reorganization of subjects and curriculum planning that is bound to favour the acquisition of self-awareness strategies, inasmuch as it emphasizes the personal work of students and the close tutoring and assessment of their development. The new ECTS credit is in entire accordance with the issues of selfdiagnosis and management of personal work. Hence, the pertinence of the model proposed here. Nevertheless, there is more to our proposal than just a methodological shift. The beginning of the $21^{\text {st }}$ century is witnessing quick changes in society, such us the development of multicultural communities, or the challenges posed by globalization (Ruiz-Cecilia, 2007). The world of ELT (English Language Teaching) is heading towards a humanistic, multidimensional approach, in which existential aspects acquire an important role. Education (in the global sense of bringing out the students' personal and social capacities, attitudes and values) backs up the very process of teaching the new language. Given the new educational challenges, it is essential to familiarize future teachers with self-assessment techniques. Therefore, the current situation calls for a reorientation of language teaching in order to explore the possibilities of languages to build concepts and relations, as instruments of humanization and mutual understanding.

If teachers are to assume new roles in the arena of an evolving reality, their training must be reinforced to provide the required expertise (Delors 1996, Esteve 2003). In this regard, Jokinen and Saranen (1998) point out the importance of developing trainees' critical capacity and introducing systematic self-assessment from the very beginning. In their view, the ability of schools to respond to the demands of society depends mainly on the capacity of teachers to assess their own potentials.

With the above considerations in mind, during the academic year 2007/08 we conducted a methodological revision of several subjects in the degree of Foreign Language Teachers, as part of a pilot project implemented in the Faculty of Education in Granada to promote transition towards the European system

\section{Pedagogical and epistemological contexts}

\subsection{Self-assessment: the need to (re)construct the teaching self}

One of the most outstanding occurrences in education -particularly from the fifties onwards- has been the move towards a change in the role of the students, henceforward envisaged as agents of their own learning. Such a development has its theoretical underpinnings in the progressive movement, the constructivist model of learning and developmental psychology. At University level, this approach is difficult to implement in our own context in the Faculty of Education of Granada, given the high student-lecturer ratio. Nevertheless, we are trying to put into practice a model centred round the personal 
work of students and the close tutoring and assessment of their development, with a view to strengthening the practical preparation of would-be teachers.

If students must become responsible for their own learning process, it is essential to pay attention to their own discourse. In accordance with recent pedagogical theory (postmodernism, critical thinking, critical pedagogy) we adopt a dialogical approach, placing the voices and critical capacity of the students centre stage (Harding 1991) and allowing trainees to benefit from collaborative work. The final aim is that of enabling students to elaborate their own reflections and criteria. Of particular interest are the theories of Pinar (1988), who highlights the need to consider teachers in a holistic sense, as persons, not mere passers of knowledge. The scholar employs a beautiful metaphor to refer to the process of teacher formation, namely "the architecture of the self". The self should be constructed and reconstructed in the lifelong process of be(com)ing a teacher.

This should be the basis of professional action, for indeed the whole personality is at work when teaching. In this sense, Bolívar, Domingo \& Fernández (2001) recommend the use of narrative devices (such as the portfolio), given the potential of narration to construct and reconstruct the self. In this sense, the main device introduced in our course was the construction of an individual, extended narrative, in the form of a portfolio.

The portfolio in language teaching was defined by Paulson et al. (1991: 60) as "a purposeful collection of student work that exhibits the student's efforts, progress and achievements in one or more areas. The collection must include student participation in selecting contents, the criteria for selection, the criteria for judging merit and evidence of student self-reflection". In recent years, Barrett (2010) has done extensive work on the use of electronic portfolios in several disciplines, among them Teacher Education. Her results are widely acknowledged and add a promising perspective for the use of portfolios at university level. In our experience, the very idea of the portfolio has materialized as a personal production and compilation of the daily work, which enabled both the student and the trainer to see personal effort and evolution of the learning process. It served as an appraisal instrument for the trainer, but mostly as a self-assessment and metacognitive tool for students, who became aware of their own strong points and learning needs in the process of producing this extended narrative. In their portfolios, students collected their observations, reflections, personal accounts of meaningful events taking place during the course, and analyses of such events. The portfolio itself generated the means by which the weak points and shortcomings could be confronted, since students could rewrite the material and hand it in to the trainer for correction, or further develop those aspects considered relevant for their own learning. In that way, they constructed their own knowledge according to their personal requirements and learning styles.

Central to our work was the issue of metacognition, defined by Taylor (1999) as "an appreciation of what one already knows, together with a correct apprehension of the learning task and what knowledge and skills it requires, combined with the agility to make correct inferences about how to apply one's strategic knowledge to a particular situation, and to do so efficiently and reliably." More specifically, we envisage metacognition as the cognitive awareness of trainees regarding the mental processes involved in their learning acts, particularly those oriented towards their professional development. Therefore, we help students to observe themselves while performing their tasks. 
Together with the portfolio, another methodological tool to encourage students' management and metacognition of the learning process as well as fostering autonomous skills was that of the so called 'project work', namely group work developed throughout the course and presented to the class by the group members as part of the subject's curriculum.

Finally, we followed Hainmuller's proposals (2005) regarding the importance of early diagnosis in the education of future teachers. According to this scholar, once the learning fields are identified, students can work to improve their weak points, while teachers may provide individualized training and strategies in order to address those needs. This approach aims at bringing out the potentials of the person in a holistic sense, and is likely to create a genuine 'learning organization', since the work involved implies reflection and change for both trainers and trainees. In this respect, we devised a questionnaire, which served as a first approach to the trainees' judgements and perceptions in relation to their professional competence, attitudes, and previous knowledge. The questionnaire was answered by the students in one of the first sessions, and it was re-administered at the end of the course.

\subsection{The course Literature Teaching in the context of the teacher training curriculum}

Our course focuses on the role of literature in the education of future teachers of English to non-native speakers (mostly at Primary and Low Secondary levels.) Since the course is part of the final year of their training, we pursued the double aim of both offering the specific instruction pertaining to the subject and providing students with self-assessment strategies and reflective skills, in order to enhance their preparation as future teachers of English.

In order to programme the course, we initially posed the following question: 'What are the formative needs of trainees in relation to literature?' (Pérez-Valverde 2005). Nowadays, when dealing with the teaching of English in Primary, many voices are in favour of introducing a discourse-based approach, namely one in which the students are presented with complete instances of language (Rigg 1991). Learners thus undergo an immersion process, which purports to reproduce the phenomena involved in the acquisition of the mother tongue. In this sense, working with a whole text will enable learners to surpass the level of words and sentences and invite them to elicit meaning from a complete piece of discourse. (This approach, nonetheless, is combined with the traditional bottom-up approach, which focuses on the smallest linguistic units -vocabulary, grammar- and evolves from these to the largest ones: text, discourse).

The use of literature can favour the adoption of discourse-based approaches in the foreign language classroom. Working with stories and narratives in Primary provides opportunities to develop discourse competence in meaningful and playful contexts. In this sense, it is essential to look for age and language-appropriate material likely to appeal to young learners, in order to engage them in authentic communication, thus fostering interaction. 
In light of the above, the following specific learning objectives were proposed:

- To develop a positive attitude towards reading and working with literary texts and other fictional material (i.e. films) in the language classroom

- To become familiar with texts for children and teenagers in English

- To be able to work successfully with storytelling, picture books, prose texts, poetry and drama

- To become aware of the role of culture and values when working with literature

- To become competent readers of literary texts in English

- To become familiar with recent trends in the field of literary reception

Together with the need to identify material appropriate for the Primary classroom, it is important to know how to use such material. Thus, we worked with storytelling, adaptation of stories, narrative techniques, analysis of different types of books (picture books, toy books...) and their possibilities in the FL classroom, as well as different types of poetry (nursery rhymes, concrete poems, limericks, etc.), creative writing and drama. Likewise, trainees were made aware of the fact that texts offer a particular vision of the world, assign a given role to each character, reflect particular situations... The sociocultural patterns and roles that appear in texts for children may help to perpetuate a particular vision of things (for instance, gender relations) or, on the contrary, help to change the status quo.

Furthermore, we sought to improve the reading and literary competence of the trainees (Mendoza-Fillola 2007 and Pérez-Valverde 2005). For this, we introduced a reading list including contemporary short stories. In order to engage them into reading, while improving their analytical and interpretive skills, we devoted a weekly session to the practice of the reading workshop, where ideas, feelings and opinions were shared. As a specific part of their portfolio, students also completed a reading journal that gathered their personal reading experience.

The course was thus oriented towards the development of basic competencies, in order to prepare students for their future practice. It was our purpose to help them acquire teaching abilities related to the following issues:

- Selecting texts appropriate to different stages and levels, taking into consideration the linguistic and cognitive development of their future students.

- Working with texts from an interdisciplinary perspective and being able to employ different techniques, according to current methodology.

- Using a wide range of children's books (wordless books, picture books...) as helpful instruments of initiation into the basic skills of the foreign language.

Also, our students had to be (or become before the completion of the course) competent readers in the FL, with a particular focus on literary texts.

In sum, from the standpoint of our subject's specificity, the development in trainees of both literary and pedagogic competencies was our main concern, together with the practice of the foreign language itself. At the same time, the methodological devices employed were oriented to foster collaborative work, autonomous learning, critical thinking, 
management of ICT, and, as stated before in this paper, encourage metacognition and selfassessment capacity, in order to monitor and evaluate their professional development as teachers.

\section{Method}

\section{Context}

The experience was conducted at the Faculty of Education (University of Granada, Spain). The pilot project was implemented throughout the academic year 2007-2008. We believe that University teachers should be well acquainted with the concepts of selfassessment, metacognition, and professional competence in order to be successful in their teaching career.

\section{Participants}

Fifty students (62\% female) from the University of Granada who were enrolled in a literature teaching course participated in the study. The mean age was 20.4 years old (range 20-29).

\section{Procedure}

The starting point of our experience was the devisal of a 13-item 5-point Likert-type questionnaire, aimed at introducing our students to the practice of self-assessment, while measuring their previous knowledge of the ECTS system. The highest (positive) score that could be attained on the measure was 65; the lowest (negative) score was 13. Although it used a Likert-type scale, it also provided the opportunity to add the necessary comments for each of the items, thus including a qualitative orientation. It was answered at the beginning and at the end of the course (to shed light on both the individual improvement and the development of the class as a group), and included the following items:

a) Self-assessment in relation to professional competence:

- linguistic competence: capacity to use the foreign language in the context of the classroom

- use of ICT (Information and Communication Technologies in Education)

- autonomous work

- collaborative work

- initiative to participate in the organization of the subject (design of tasks, oral presentations)

- use of bibliography

b) Items related to the ECTS methodology:

- knowledge of the ECTS

- expectations with regards to the implementation of the new methodology (difficulties, assets, relevant aspects) (open item)

- degree of familiarization with a creative methodology designed to highlight the students' potentialities 
- degree of familiarization with a learning system based on the development of competencies

c) Attitudinal items:

- degree of motivation to work in a personal, autonomous way

- attitude towards learning through discovery, critical reflection, and inquiry

- degree of motivation to actively participate in the programming and development of the subject.

The second lesson was devoted to the introduction of the portfolio and some time was spent posing clear examples on what it really is and how it should be completed. In order to collect information for the subsequent qualitative analysis, we relied on the material gathered in the portfolios, as well as in our own observation of their performance while producing and presenting to the class the project work devised in groups throughout the course. Thus, in one of the initial sessions the students decided on the topics for the production of such work. The idea was to expose them to situations liable to help them identify their own position (achievements, learning fields) with a special focus on the subject of literature in the English class. The very processes of working on the devisal and organization of the work, and its presentation to the class in English, provided them with objective data to detect their weak and strong points in relation to the professional competences itemized in the questionnaire (oral skills in the foreign language, capacity to work in a collaborative manner, initiative to plan actions and tasks, mastering of new technologies...).

\section{Analysis and discussion of results}

After the experience, the questionnaires were analysed using SPSS (Statistical Package for the Social Sciences) (see table below). The data show a perceived significant improvement in the capacity to work autonomously: from 3.24 to 4.11 , and a great increase in the knowledge of the European credit: 1.97 - 3.63. In this sense, while 55 percent of the students claimed to have scarce knowledge of the European system at the beginning of the course, in the final questionnaire 69 percent declared having a good knowledge of it. They likewise consider that their capacity to both work with a creative methodology $(3.48$ - 4.05) and a system based on competences $(3.09-3.89)$ have increased. It is noteworthy that their evaluation of their own linguistic competence and initiative to participate in class observes a smaller difference. From their own comments pertaining to such items, it follows that they have become aware of their needs and weak points. They state that they are aware of their improvement, but consider there is still a long way to go. Finally, regarding motivation and attitudes, if they already manifested a high level of motivation and a positive attitude towards the type of work proposed, the development of the subject has reinforced their interest in this active methodology. 
Table 1. Results of initial and final questionnaires.

\begin{tabular}{|l|l|l|l|l|}
\hline Items & Initial & S.D. & Final & S.D. \\
\hline 1. Linguistic competence & 3.55 & .794 & 3.79 & .855 \\
\hline 2. Use of ICT & 2.79 & .740 & 3.47 & .964 \\
\hline 3. Autonomous work & 3.24 & 1.091 & 4.11 & .459 \\
\hline 4. Collaborative work & 4.03 & .847 & 4.42 & .692 \\
\hline 5. Initiative to participate... & 2.40 & .70 & 2.88 & .77 \\
\hline 6. Use of bibliography & 3.33 & .71 & 3.68 & .51 \\
\hline 7. Knowledge of the ECTS & 1.97 & .684 & 3.63 & .597 \\
\hline 8. Expectations ECTS & 3.22 & .67 & 3.61 & .60 \\
\hline 9. Familiarization creative methodology & 3.48 & .795 & 4.05 & .524 \\
\hline 10. Familiarization system based on competences & 3.09 & .765 & 3.89 & .459 \\
\hline 11. Motivation to work autonomously & 4.06 & .659 & 4.33 & .594 \\
\hline 12. Attitude learning through discovery & 3.88 & .820 & 4.05 & .524 \\
\hline 13. Motivation to participate & 3.94 & .788 & 4.26 & .653 \\
\hline
\end{tabular}

With respect to the main instruments used in the course, namely the portfolio and the projects devised in groups, they have both proved to be highly useful for the achievement of our goals. Monitored by the tutor, each student evaluated his/her progression in relation to the detected learning fields. The fact that they became personally engaged in the assessment of their own progress positively influenced the final marks and academic results of the course, for, once the learning fields were identified, trainees tended to work on their weak points and look for ways to overcome their difficulties. In this sense, the final marks of the students were considerably higher than those obtained in previous years in this course. Both throughout the course and at the end of the year, students expressed their satisfaction with the methodology adopted. From this experience onwards, the portfolio is one of the key practices in the subject of literature teaching.

Since, as has been said, students need to become familiar with classroom practices pertaining to the level of Primary, the topics dealt with in group work are related to a) planning and presentation of didactic material; b) small action research projects conducted within the boundaries of the class. This very much helped to foster the students' initiative and level of involvement in the construction of contents. The materials produced can be used in subsequent years, and provided them with a working model for their future practice as language teachers. The following are some examples of the presentations of group work carried out:

- Storytelling in Primary: This study addressed the issue of narration in class. It included bibliographic search, personal reflection on the topic, selecting a story, planning a CD interactive presentation (The Very Hungry Caterpillar, by Eric Carle).

- Creative writing in the language classroom. This group studied the processes of poetic composition, and proposed several easy patterns to write poetry (thin poems, focusing first line, diamonds, etc.)

- Comparative study between the trainees' reading competence in L1 and L2, based on a number of literary texts. The authors of this project designed several questionnaires to study the differences in the reading processes in the mother 
and the foreign language. This project helped to establish theory-practice relations concerning reading processes.

The portfolios or extended narratives produced had both a descriptive and an analytic side. At one level, they gathered the whole work produced during the year. Thus, they included:

- personal elaboration of the contents and aspects dealt with in class

- hand-outs and notes prepared by teacher

- bibliographical revision of key aspects

- the so-called reading journals, produced as part of the extensive reading programme included in the course. The observation of the mechanisms engaged in their reading experience enabled the students to approach the phenomena of literary reception and reading in the FL 'from the inside'. Before, while, and especially after reading a given text, the students noted down their reflections in the journals. The aspects gathered in the journal encompassed the following: predictions about content, emotions and associations propitiated by the fictional universe presented in the text (character, topics, circumstances), relationships established with own life and external reality, relations with other texts (intertextuality), as well as linguistic difficulties

- creative writing texts (poems, short stories) produced as part of a writing workshop conducted throughout the year

- activities, tasks, and papers produced and/or presented in class. As stated before, most of our time was devoted to tasks oriented towards constructing knowledge through action, according to the 'learning by doing' principle

- the project work produced throughout the year.

However, as we understand it, the portfolio is by no means a compendium of knowledge and procedures. Quite on the contrary, there is also room for analysis and personal reflection, particularly so with respect to a) individual learning progression, and b) organization of sessions (contents introduced, tasks performed, response of the class, works presented). It thus articulates both personal experience and the observation of the class as a group. In this respect, as stated by Bolívar, Domingo \& Fernández (2001: 36), reflection through narrative devices allows the individual to become both a researcher of his/her own evolution and a subject of his/her own observation at once. In our own experience, the portfolio proved to be a successful instrument in order to engage students in self-reflection. It helped students internalize metacognitive strategies and enhanced the process of self-awareness, favouring the exploration of internal strategies and mental models. The portfolios were periodically supervised in tutorial meetings.

These are some examples of the type of comments included in the portfolios:

\section{a) description of session and personal judgement:}

The tutor organizes the class to work in different ways. We can work by ourselves, in small groups, in pairs or the whole class. Today we have worked in small groups and I think that it is very important and productive since the collaborative work is fostered and we can benefit from the knowledge of our classmates and vice versa." 
"I think that we have practised a meaningful learning technique because we have to understand everything we do. The best way to learn is to practice and think about what we are doing."

\section{b) personal development:}

"I am learning a lot of in this subject. I learn not only information, knowledge... but I am discovering a fantasy world to transfer to my pupils in the future."

"I think I am learning a lot. It is very interesting to know about the way in which we can work with children: there is a fantastic variety of activities we can use. I have never thought in so many possibilities: rhymes, tongue twisters, activities before-duringafter the story... I am discovering a new way to enjoy literature: a different point of view."

"I feel more confident and relaxed speaking aloud in class. I think I have overcome my fear to speak in English, and although I still make mistakes I don't worry about them. I want to improve speaking, of course. But now, the mistakes I could make are not a handicap to participate in class and I'm very happy for that."

The following extract gives a clear view of the experience, as felt by one of the trainees:

"This portfolio is the result of a very personal project. I have worked very hard day by day. I was very excited about this work. The fact of writing a portfolio helped me to reflect about all that happened in class, involving me in the subject, searching for additional information and improving my working habits. I liked working individually but I also felt very well working with my classmates. Working in a group is a useful way to learn from other people. I have learned in this subject the importance of Children's Literature, because books, stories, tales, etc. could help boys and girls to learn attitudes and values. This type of literature has special educational value. I realized that children could love reading if the stories presented are interesting for them. I have improved my English comprehension and I have begun to enjoy reading books in English for pleasure (although it was hard at the beginning). I am satisfied with my work although I know that it is only the beginning of the magical adventure of English culture and literature knowledge. Finally I would say that the subject evaluation is all right, because the teacher considers the whole process of learning, and not only the final result (a final exam, for example). That is a prize to the continuous effort during these months."

\section{Conclusions}

The methodological innovations carried out in order to adapt the subject of literature teaching to the European credit system have been very positively valued by both trainees and trainer. The experience has proved that it is possible to implement the transition towards the ECTS in a successful manner, provided that institutions are endowed with the necessary infrastructure. In our case, it was the teachers' task to compensate for the high ratio (50 students were enrolled in the course) with extra work and careful planning of the actions. Notwithstanding this circumstance, for all the participants, the benefits of 
a teacher training model based on the acquisition of competences, in which the studentsteachers become responsible for their own improvement, have been suitably demonstrated.

\section{REFERENCES}

Barrett, H. (2010). "Balancing the Two Faces of ePortfolios", in Educação, Formação \& Tecnologias, 3(1): 6-14. [Online], available from: http://eft.educom.pt, accessed 16 March, 2010.

Bolívar, A., Domingo, J., and Fernández, M. (2001). La investigación biográfico-narrativa en educación. Madrid: La Muralla.

Delors, J. (ed.) (1996). Learning: the treasure within. Report to Unesco of the International Commission on Education for the Twenty-first Century. Paris: Unesco Publishing.

Esteve, J.M. (2003). La tercera revolución educativa. La educación en la sociedad del conocimiento. Barcelona: Paidós.

Ghosn, I.K. (2002). "Four good reasons to use literature in the primary school ELT", in English Language Teaching Journal, 56: 172-179.

Hainmuller, B. (2005) "Identifying the potentials for teaching - a promising new approach to teacher training and change management in schools?", in M. Persson (ed.), Learning for the future - Dimensions of the new role of the teacher. Karlstad: The Learning Teaching Network, 121-134.

Harding, S. (1991). Whose science? Whose knowledge?. Ithaca, N.Y.: Cornell University Press. Jokinen and Saranen (1998). "Development of students' teachers self-assessment", in H. Jokinen and J. Rushton (eds.), Changing Contexts of School Development. The Challenges to Evaluation and Assessment. Jyvaskyla: Institute for Educational Research, University of Jyvaskyla, 1-18.

Kembo, J. (1993). "Reading: encouraging and maintaining individual extensive reading", in English Teaching Forum, 31/2: 36-38.

Mendoza-Fillola, A. (2007). Materiales Literarios en el Aprendizaje de la Lengua Extranjera. Barcelona: ICE-Horsori.

Paulson, F.L., Paulson, P.R., and Meyer, C.A. (1991). "What makes a portfolio a portfolio?", in Educational Leadership, 48(5): 60-63.

Pérez-Valverde, C. (2005). "Innovación docente en didácctica en didáctica de la literatura en lengua inglesa", in C. González and D. Madrid (eds.), Estrategias de innovación docente en didáctica de la lengua y la literatura. Granada: Grupo Editorial Universitario, 145-164.

Pinar, W.F. (1988). "Autobiography and the architecture of the self", in Journal of Curriculum Theorizing, 8 (1): 7-36.

Rigg, P. (1991). "Whole Language in TESOL", in Tesol Quarterly, 25 (3): 521-547.

Ruiz-Cecilia, R. (2007). El texto literario multicultural: espacios liminares para la creación de identidades transculturales, in R. Sánchez (ed.), Lecciones azules. Madrid: Visor, 443-456.

Taylor, S. (1999). "Better learning through better thinking: developing students' metacognitive abilities", in Journal of College Reading and Learning, 30 (1). Retrieved November 9, 2007 from Expanded Academic Index ASAP. http://electronicportfolios.org/, accessed 17 March, 2010. 